\title{
GAMBARAN COUNTERPRODUCTIVE WORK BEHAVIOR (CWB) PT X (PERUSAHAAN KONSTRUKSI DI JAKARTA)
}

\author{
Baquandi Lutvi Yoseanto \\ Magister Profesi Psikologi, Universitas Tarumanagara \\ Email:baquandilutviyoseanto@gmail.com
}

\begin{abstract}
ABSTRAK
Data keuangan, hasil wawancara peneliti dengan karyawan dan eks karyawan, data temuan Cost Control, data absensi karyawan mengindikasikan terdapat penyimpangan keuangan di PT X yang dalam istilah psikologi termasuk perilaku Counterproductive Work Behavior (CWB). Counterproductive Work Behavior mempunyai dua dimensi yaitu Counterproductive Work Behavior Organizational (CWBo) yaitu perilaku yang langsung mengancam atau membahayakan organisasi dan Counterproductive Work Behavior interpersonal (CWBi) yaitu perilaku yang langsung mengancam atau membahayakan individu yang berada di dalam organisasi tersebut. Peneliti ingin mendapatkan gambaran CWB, CWBo, CWBi serta perbandingan antara CWBo dengan CWBi di PT X. Jenis penelitian adalah kuantitatif dengan metode penelitian simple random sampling. Sampel yang diambil sejumlah 31 orang. Kesimpulan dari penelitian ini adalah Secara deskriptif, partisipan laki-laki $(93,5 \%)$ lebih banyak daripada partisipan perempuan (6,5\%) dan karyawan terbanyak adalah lulusan S1 (48,4\%), kemudian SMA (25,8\%), S2 (16,1\%) dan Diploma (9,7\%). Tingkat CWB di PT X tergolong sedang (skor $z=.087$ ), tingkat CWBo termasuk kategori sedang (skor $z=.097)$, dan tingkat CWBi tergolong dalam kategori sedang (skor $z=.077)$. Tidak ada perbedaan antara rata-rata CWBo dan CWBi di PT X. Peneliti menyarankan agar ada penelitian yang lebih komprehensif terutama dengan melibatkan subjek yang lebih besar sehingga bisa dilakukan analisis yang lebih baik dan mendalam dan dilakukan secara anonim.
\end{abstract}

Kata kunci: Counterproductive Work Behavior, perusahaan konstruksi, Jakarta

\section{PENDAHULUAN}

\section{Latar Belakang}

PT X adalah perusahan yang bergerak di bidang konstruksi jalan raya. Perusahaan ini telah berdiri selama 40 tahun lebih dan telah membangun jalan di berbagai daerah di Indonesia. Ada dua proses bisnis yang terjadi di perusahaan ini, yaitu Proses Marketing dan Proses Produksi (pelaksanaan proyek). Pencapaian marketing di bandingkan target di PT X terus meningkat selama tiga tahun terakhir. Pencapaian marketing terhadap target pada tahun 2013 adalah 6\%, pada tahun 2014 adalah 33\% dan pada tahun 2015 sebesar 56\% yang dapat dilihat di tabel 1. Dari data tersebut, dapat dilihat bahwa meskipun belum tercapai target marketing, secara umum terjadi peningkatan kinerja di bagian proses bisnis marketing.

Tabel 1 Tabel Data Marketing PT X

\begin{tabular}{llll}
\hline \multicolumn{1}{c}{ Uraian } & \multicolumn{1}{c}{2013} & \multicolumn{1}{c}{2014} & \multicolumn{1}{c}{2015} \\
\hline Target & $916 \mathrm{M}$ & $836 \mathrm{M}$ & $1.029 \mathrm{M}$ \\
\hline Realisasi & $53 \mathrm{M}$ & $272 \mathrm{M}$ & $572 \mathrm{M}$ \\
\hline$\%$ Pencapaian & $6 \%$ & $33 \%$ & $56 \%$ \\
\hline
\end{tabular}

Proses produksi atau pelaksanaan proyek adalah proses mengerjakan dan menyelesaikan proyek yang sudah diperoleh marketing. Output dari proses produksi adalah harga pokok pendapatan. Harga pokok pendapatan adalah komponen utama yang menentukan laba rugi perusahaan. Berdasarkan data keuangan PT X didapatkan informasi bahwa harga pokok pendapatan PT X selama tiga tahun terakhir semakin besar dan melebihi standar industri kontraktor jalan yaitu sebesar: $105 \%$ di tahun 2013; 108\% dia tahun 2014 dan 109\% dia tahun 2015. Beban usaha PT $\mathrm{X}$ tergolong stabil meskipun berada di atas standar yang telah ditetapkan yaitu sebesar: $8 \%$ di 
tahun 2013; 9\% di tahun 2014; dan 8\% di tahun 2015. Harga pokok pendapatan dan beban usaha yang melebihi standar yang telah ditetapkan mengakibatkan laba / rugi usaha semakin minus atau semakin merugi yaitu sebesar: $-13 \%$ di tahun 2013 ; $-16 \%$ di tahun 2014 ; dan $-17 \%$ di tahun 2015. Besarnya harga pokok pendapatan mengakibatkan semakin besar biaya bank yaitu sebesar: $2 \%$ di tahun 2013; 7\% di tahun 2014 dan 10\% di tahun 2015. Biaya pajak menambah besarnya laba / rugi bersih yang semakin merugi yaitu sebesar: -18\% di tahun 2013, -28\% di tahun 2014 dan $-31 \%$ di tahun 2015 yang bisa dilihat di tabel 2. Berdasarkan data tersebut terlihat terdapat masalah di proses produksi.

Tabel 2 Tabel Data Keuangan PT X

\begin{tabular}{cllll}
\hline Uraian & 2013 & 2014 & 2015 & Standar Industri Kontrator Jalan \\
\hline Harga Pokok Pendapatan & $105 \%$ & $108 \%$ & $109 \%$ & $<90 \%$ \\
Biaya Langsung & $81 \%$ & $85 \%$ & $91 \%$ & \\
Biaya Tidak Langsung & $24 \%$ & $22 \%$ & $18 \%$ & \\
\hline Beban Usaha & $8 \%$ & $9 \%$ & $8 \%$ & $3-4 \%$ \\
\hline Laba (Rugi) Usaha & $-13 \%$ & $-16 \%$ & $-17 \%$ & $6-7 \%$ \\
\hline Biaya Bank & $2 \%$ & $7 \%$ & $10 \%$ & $1.5 \%$ \\
\hline Laba (Rugi) Sebelum Pajak & $-15 \%$ & $-24 \%$ & $-28 \%$ & $5.5 \%$ \\
\hline Laba (Rugi) Bersih & $-18 \%$ & $-28 \%$ & $-31 \%$ & $2-5 \%$ \\
\hline
\end{tabular}

Peneliti mencoba mencari data permasalahan yang terjadi di proses produksi. Berdasarkan data sekunder berupa hasil temuan Cost Control dan wawancara dengan beberapa karyawan yang masih menjadi karyawan PT X maupun karyawan yang sudah keluar, didapatkan data bahwa terdapat beberapa dugaan penyimpangan / fraud yang terkait dengan kegiatan di proyek yang dapat dilihat pada tabel 3 . 
Tabel 3 Dugaan Penyimpangan di PT X

\begin{tabular}{|c|c|c|}
\hline $\begin{array}{c}\text { Dugaan } \\
\text { Penyimpangan }\end{array}$ & Pihak yang Terlibat & Mekanisme Dugaan Penyimpangan \\
\hline $\begin{array}{l}\text { Kekurangan data } \\
\text { laporan keuangan }\end{array}$ & $\begin{array}{l}\text { Finance, penerima uang } \\
\text { muka (pelaksana, pihak } \\
\text { eksternal) }\end{array}$ & 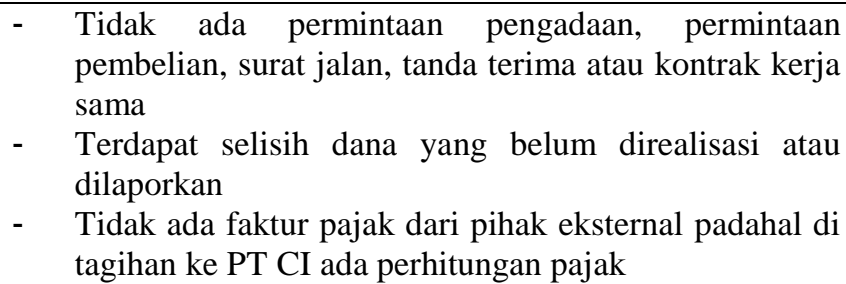 \\
\hline karyawan & $\begin{array}{l}\text { Pelaksana, } \\
\text { Proyek }\end{array}$ & $\begin{array}{l}\text { - Pelaksana melaporkan jumlah karyawan harian yang } \\
\text { lebih besar daripada jumlah sebenarnya kepada } \\
\text { Finance Proyek } \\
\text { - Finance Proyek melaporkan data tersebut kepada } \\
\text { Finance HO (dengan tanda tangan pimpinan proyek / } \\
\text { General Superintendent) }\end{array}$ \\
\hline $\begin{array}{l}\text { Volume } \\
\text { subkon }\end{array}$ & Pelaksana, Surveyor & 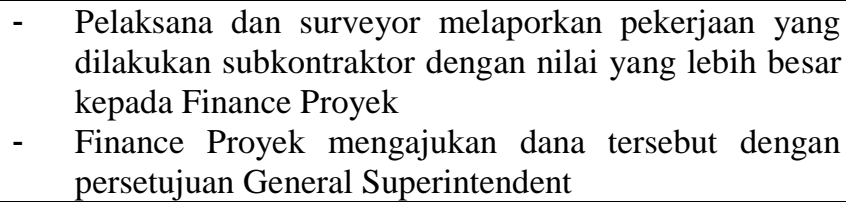 \\
\hline Rental Alat & $\begin{array}{l}\text { Pelaksana, Operator Alat } \\
\text { Berat }\end{array}$ & $\begin{array}{l}\text { - Pelaksana dan operator melakukan pekerjaan sipil dan } \\
\text { uang hasil rental alat tersebut tidak disetorkan ke } \\
\text { perusahaan. } \\
\text { - Solar dan maintenance alat berat menjadi tanggung } \\
\text { jawab perusahaan }\end{array}$ \\
\hline Pencurian solar & $\begin{array}{l}\text { Operator Alat Berat dan } \\
\text { Security }\end{array}$ & $\begin{array}{ll} & \text { Alat berat di isi BBM pada sore hari } \\
\text { - } & \text { Pencurian terjadi di malam hari } \\
\text { - } & \text { Satu alat berat bisa di curi sekitar } 50 \text { L. Harga per liter } \\
& \text { bisa dijual Rp. } 6000,00\end{array}$ \\
\hline Pembelian material & Pelaksana, logistik & $\begin{array}{l}\text { - } \quad \text { Pembelian material dengan harga diatas harga yang } \\
\text { sebenarnya } \\
\text { - } \quad \text { Ada transaksi pembelian tanpa adanya barang }\end{array}$ \\
\hline
\end{tabular}

Bukti lain penyimpangan di PT X adalah temuan Cost Control yang melakukan pemeriksanaan terhadap laporan keuangan proyek R periode 3 Oktober 2016 sampai dengan 31 Januari 2017 yang terdapat di tabel 4.

Tabel 4 Rekapitulasi Hasil Temuan Cost Control PT X

\begin{tabular}{lllll}
\hline Keterangan & Oktober 2016 & November 2016 & Desember 2016 & Januari 2017 \\
\hline Total Transaksi & 128 & 57 & 41 & 33 \\
\hline Transaksi bermasalah & 43 & 5 & 21 & 17 \\
\hline Persentase Transaksi bermasalah & $34 \%$ & $9 \%$ & $51 \%$ & $52 \%$ \\
\hline Total Dana & 3.990 .878 .140 & 1.492 .607 .381 & 532.182 .205 & 422.584 .082 \\
\hline Dana bermasalah & 837.100 .108 & 56.875 .000 & 390.000 .000 & 292.014 .046 \\
\hline Persentase dana bermasalah & $21 \%$ & $4 \%$ & $73 \%$ & $69 \%$ \\
\hline
\end{tabular}

Karyawan PT X juga sering meninggalkan pekerjaan dengan berbagai macam alasan di luar ketentuan perusahaan, misalnya alasan tidak punya uang untuk makan di proyek, mengantar anak sekolah, dan alasan lainnya. Data absensi karyawan dapat dilihat di tabel 5. 
Tabel 5 Rekapitulasi Absensi Karyawan Proyek Cikupa Tahun 2017

\begin{tabular}{llllll} 
& Januari & Februari & Maret & April & Mei \\
\hline Rata-Rata kehadiran & $53 \%$ & $82 \%$ & $82 \%$ & $48 \%$ & $27 \%$ \\
\hline
\end{tabular}

Fenomena di atas yaitu penyimpangan dalam proses produksi serta ketidakhadiran karyawan adalah suatu tindakan pelanggaran terhadap norma organisasi atau mengganggu orang di dalamnya yang dalam istilah psikologi termasuk dalam kategori Counterproductive Work Behavior (CWB) (Bennett \& Robinson, 2000). Koopmans et al, 2011 menjelaskan bahwa kinerja karyawan dalam tiga dimensi yaitu Task performance (kinerja berdasarkan tugas), Contextual Performance (perilaku yang membantu dalam konteks lingkungan kerja) dan Counterproductive Work Behavior (perilaku yang menghambat tujuan organisasi misalnya pencurian). Perilaku CWB yang dilakukan oleh karyawan PT X diduga telah mengakibatkan perusahaan mengalami kerugian yaitu rugi 18\% di tahun 2013, rugi 28\% di tahun 2014 dan rugi $31 \%$ di tahun 2015 yang bisa dilihat di tabel 2.

Dari fenomena tersebut tujuan Peneliti adalah ingin mencari tahu gambaran Counterproductive Work Behavior (CWB), Counterproductive Work Behavior Organizational (CWBo), Counterproductive Work Behavior interpersonal (CWBi) serta perbedaan antara Counterproductive Work Behavior Organizational (CWBo) dengan Counterproductive Work Behavior interpersonal (CWBi) karyawan di PT X.

\section{Rumusan Masalah}

Rumusan masalah dalam penelitian ini adalah bagaimana gambaran Counterproductive Work Behavior (CWB) karyawan di PT X?, bagaimana gambaran Counterproductive Work Behavior Organizational (CWBo) karyawan di PT X? dan bagaimana gambaran Counterproductive Work Behavior interpersonal (CWBi) karyawan di PT X?, apakah ada perbedaan antara Counterproductive Work Behavior Organizational (CWBo) dengan Counterproductive Work Behavior interpersonal (CWBi) karyawan di PT X?

\section{TEORI}

\section{Definisi CWB}

Ada beberapa definisi CWB yang diajukan beberapa ahli. Peneliti akan menyebutkan dua definisi dari dua pakar yang paling sering dijadikan referensi yaitu Bennett \& Robinson dan Spector. Menurut Bennett \& Robinson (2000), CWB adalah suatu keadaan karyawan kurang termotivasi untuk memenuhi harapan sosial/norma sosial atau termotivasi untuk menentang harapan tersebut, dengan melakukan tindakan pelanggaran terhadap norma organisasi atau mengganggu orang di dalamnya. Definisi lain menyebutkan bahwa CWB adalah perilaku yang disengaja yang merugikan atau bermaksud merugikan organisasi dan anggota di dalamnya (Spector, Fox, Penney, et al, 2006). Dari dua definisi di atas, peneliti menyimpukan bahwa CWB adalah perilaku yang merugikan organisasi maupun orang di dalamnya.

\section{Dimensi CWB}

Dimensi CWB juga akan penulis sebutkan menurut pandangan Bennett \& Robinson dan Spector. Menurut Bennett \& Robinson (2000), Counterproductive Work Behavior mempunyai dua dimensi. Dimensi pertama adalah Counterproductive Work Behavior Organizational (CWBo) yaitu suatu perilaku yang langsung mengancam atau membahayakan organisasi, seperti perilaku mencuri barang-barang perusahaan, datang telat ke kantor tanpa izin dan memberikan sedikit 
usaha dalam melakukan pekerjaan. Dimensi kedua adalah Counterproductive Work Behavior interpersonal (CWBi) yaitu suatu perilaku yang langsung mengancam atau membahayakan individu yang berada di dalam organisasi tersebut, seperti perilaku mencemooh rekan kerja, mengucapkan sesuatu yang dapat menyakiti seseorang di tempat kerja dan mengejek rekan kerja. Sedangkan dimensi CWB menurut Spector, Fox, Penney, et al (2006) memiliki lima dimensi. Dimensi pertama adalah Abuse Against Others meliputi perilaku berbahaya yang ditujukan kepada rekan kerja dan orang lain yang membahayakan baik secara fisik maupun psikologis melalui ancaman, komentar buruk, mengabaikan orang tersebut, atau menurunkan kemampuan orang tersebut untuk bekerja secara efektif. Dimensi kedua adalah Production Deviance yaitu secara sengaja melakukan kegagalan terhadap tugas yang seharusnya bisa diselesaikan. Dimensi ketiga adalah Sabotage yaitu merusak perlengkapan produksi perusahaan. Dimensi keempat adalah Theft yaitu perilaku mencuri. Dimensi kelima adalah Withdrawal yaitu membatasi waktu bekerja termasuk datang terlambat, pulang lebih cepat dan istirahat melebihi waktu yang telah ditentukan. Jika diperbandingkan, dimensi CWBo dari Bennett \& Robinson sama dengan dimensi Production Deviance, Sabotage, Theft, dan Withdrawal dari Spector, Fox, Penney, et al. Dimensi CWBi sama dengan dimensi Abuse Against Others.

\section{Penyebab CWB}

Ada dua kategori penyebab CWB yang bisa dijelaskan melalui dua model. Penyebab pertama adalah Individual factors meliputi sifat bermusuhan (dispositional hostility), emosi negatif, kepribadian tipe A, impulsif, dan kecanduan narkoba (Raver, 2007). Penyebab kedua adalah situational antecedents yang meliputi persepsi keadilan dan pengawasan (Rodopman \& Spector, 2007). Ada beberapa model dalam menjelaskan Individual factors dan situational antecedents. Pada kebanyakan model, emosi dan kognisi memegang peranan penting. Pada emotion-centered stress model, dijelaskan bahwa karyawan harus menghadapi situasi-situasi yang menyebabkan stres, misalnya penilaian kinerja, konflik dan ketidakadilan. Ketika karyawan menghadapi situasi tersebut, mereka mengalami perasaan negatif misalnya benci dan cemas yang menyebabkan mereka lebih cenderung terlibat dalam perilaku berbahaya, termasuk CWB. Peran sentral emosi adalah untuk menengahi dampak kondisi lingkungan yang menimbulkan stress terhadap perilaku CWB. Pada frustration-aggression model, dijelaskan bahwa kejadian yang tidak diinginkan mengganggu pencapaian tujuan karyawan dan karena itu menyebabkan frustrasi. Ketika karyawan frustrasi, mereka mencoba mengatasi perasaan negatif mereka dengan melakukan beberapa bentuk agresi, yang mungkin ditujukan pada orang (CWBi), benda mati, atau organisasi (CWBo). Bila frustasi disebabkan oleh faktor organisasi, karyawan cenderung mengarahkan CWB mereka ke arah organisasi. Selain itu, frustrasi menyebabkan perilaku yang lebih berbahaya ketika karyawan percaya bahwa hukuman dari perusahaan tidak mungkin terjadi (Rodopman \& Spector, 2007).

\section{METODE PENELITIAN}

Penelitian ini adalah penelitian kuantitatif. Karakteristik populasi dalam penelitian ini adalah pekerja di perusahaan konstruksi, berumur antara 20-56 tahun, laki-laki maupun perempuan. Teknik sampling yang digunakan adalah simple random sampling. Sampel yang bersedia mengisi kuesioner berjumlah 31 orang (39\% dari populasi). Beberapa karyawan tidak mau mengisi kuesioner karena menganggap item kuesioner terlalu negatif. Hal ini senada dengan informasi Bennett \& Robinson (2000) di mana hanya 43\% responden yang mengembalikan atau mengisi kuesioner mereka di salah satu penelitian mereka.

Variabel dalam penelitian ini adalah Counterproductive Work Behavior. Data diperoleh dengan menyebarkan kuesioner secara online melalui google form. Pengisian kuesioner dipandu oleh 
peneliti. Kuesioner yang digunakan adalah kuesioner Workplace Deviance Scale yang sudah diadaptasi ke dalam Bahasa Indonesia oleh Suyasa pada 2013 (Bennett \& Robinson, 2000). Item CWBi terdiri dari item 21 butir yaitu item nomor 15, 26, 7, 19, 17, 29, 1, 42, 35, 36, 28, 3,12, 9, 22, 32, 38, 41, 45, 5, dan 34. Item CWBo terdiri dari 27 butir yaitu nomor 37, 2, 25, 31, 6, 10, $43,46,47,48,13,44,16,30,39,24,14,33,18,4,11,20,21,27,40,23$, dan 8. Semua item adalah item negatif misalnya "kurang mengindahkan apa yang ditugaskan oleh atasan". Pilihan jawaban adalah berapa kali intensitas dilakukan dalam sebulan: 0, 1, 2, 3, 4, dan lebih dari 4 kali.

Pengukuran reliabilitas terhadap dimensi CWBi menghasilkan angka Cronbach's Alpha 930 dengan 21 butir item. CWBi. Pengukuran reliabilitas terhadap dimensi CWBo menghasilkan angka Cronbach's Alpha 934 dengan 27 butir item. Angka tersebut menyatakan bahwa alat ukur ini reliabel, artinya konsisten jika digunakan untuk mengukur partisipan yang sama beberapa waktu kemudian.

\section{HASIL DAN PEMBAHASAN}

\section{Data Deskriptif Partisipan}

Peneliti tidak mendapatkan data demografis yang lengkap karena partisipan enggan mengisi kuesioner jika data demografis detail wajib di isi. Hal ini dikarenakan item-item kuesioner cukup sensitif bagi partisipan / semua item adalah item negatif. Hal tersebut sesuai dengan laporan Bennett \& Robinson (2000) yang menyatakan bahwa ada kesulitan untuk mengungkap perilaku CWB. Partisipan akan mengisi dengan baik kuesioner jika ada jaminan anonimitas diri subjek. Secara deskriptif, partisipan laki-laki $(93,5 \%)$ lebih banyak daripada partisipan perempuan (6,5\%). Hal ini dikarenakan karyawan di PT X biasanya ditugaskan ke luar daerah sehingga lebih banyak merekrut karyawan laki-laki. Data partisipan berdasarkan jenis kelamin dapat dilihat di tabel 6 .

Tabel 6 Deskripsi Partisipan Berdasar Jenis Kelamin

\begin{tabular}{lcc}
\hline & Jumlah & Persentase \\
\hline Laki-laki & 29 & $93,5 \%$ \\
\hline Perempuan & 2 & $5,5 \%$ \\
\hline Total & 31 & $100 \%$ \\
\hline
\end{tabular}

Karyawan inti PT X adalah S1 jurusan Teknik Sipil. Hal tersebut menyebabkan karyawan terbanyak adalah lulusan S1 (48,4\%), kemudian SMA (25,8\%), S2 (16,1\%) dan Diploma (9,7\%). Deskripsi partisipan berdasarkan jenjang pendidikan dapat dilihat pada tabel 7.

Tabel 7 Deskripsi Partisipan Berdasar Jenjang Pendidikan

\begin{tabular}{lcc}
\hline & Jumlah & Persentase \\
\hline SMA & 8 & $25,8 \%$ \\
\hline Diploma & 3 & $9,7 \%$ \\
\hline S1 & 15 & $48,4 \%$ \\
\hline S2 & 5 & $16,1 \%$ \\
\hline Total & 31 & $100 \%$ \\
\hline
\end{tabular}

\section{Gambaran CWB, CWBo dan CWBi}


Berikut ini peneliti akan menginformasikan gambaran CWB, CWBo dan CWBi di PT X. Skor CWB diubah ke skor Z untuk memudahkan kategorisasi. Kategorisasi yang digunakan adalah sebagai berikut: kategori rendah jika skor $\mathrm{z}$ kurang dari.- .5 , kategori sedang jika skor $\mathrm{z}$ antara -.5 sd .5, dan kategori tinggi jika skor z lebih dari .5.

Pada tabel 8 terlihat bahwa tingkat CWB di PT X tergolong sedang (skor $\mathrm{z}=.087$ ), tingkat CWBo termasuk kategori sedang (skor $\mathrm{z}=.097$ ), dan tingkat $\mathrm{CWBi}$ tergolong dalam kategori sedang ( skor $\mathrm{z}=.077$ ).

Tabel 8 Gambaran CWB PT X

\begin{tabular}{lcc}
\hline Variabel / Dimensi & Skor $\mathbf{Z}$ & Kategori \\
\hline CWB & .087 & Sedang \\
\hline CWBo & .097 & Sedang \\
\hline CWBi & .077 & Sedang \\
\hline
\end{tabular}

Ada beberapa faktor yang mempengaruhi pengisian kuesioner CWB yaitu item kuesioner yang semua negatif, isi kuesioner yang berisi masalah sensitif, kesediaan partisipan mengisi kuesioner, dan kejujuran partisipan dalam mengisi kuesioner (Bennett \& Robinson, 2000). Kuesioner yang itemnya negatif (misal meninggalkan tempat kerja di luar waktu yang ditentukan) sangat sensitif bagi partisipan. Hal tersebut menyebabkan beberapa partisipan enggan untuk mengisi kuesioner dan ada kemungkinan partisipan mengisi pilihan yang aman (melakukan 0 atau 1 kali dalam sebulan). Meskipun disarankan pengisian kuesioner secara anonim, peneliti masih memberikan isian (namun tidak wajib di isi) dengan harapan untuk mengambil data demografi. Namun hal tersebut membuat beberapa partisipan menolak untuk mengisi kuesioner.

\section{Perbandingan CWBo dan CWBi}

Pada tabel 9 terlihat ringkasan statistik CWBo dan CWBi. Rata-rata tingkat CWBo adalah .0974 dan sebesar .0774 untuk CWBi.

Tabel 9 Paired Samples Statistics

\begin{tabular}{lrrrrr}
\hline & & Mean & N & Std. Deviation & Std. Error Mean \\
\hline Pair 1 & cwbo &, 0974 & 31 &, 95610 &, 17172 \\
\cline { 2 - 6 } & cwbi &, 0774 & 31 & 1,06017 &, 19041 \\
\hline
\end{tabular}

Pada tabel 10 terlihat hasil korelasi antara CWBo dan CWBi yang menghasilkan angka .941 dengan nilai signifikansi .000 (kurang dari .05). Hal ini diartikan bahwa ada korelasi atau hubungan yang kuat antara CWBo dan CWBi.

Tabel 10 Paired Samples Correlations

\begin{tabular}{lrrrr}
\hline & & $\mathrm{N}$ & Correlation & Sig. \\
\hline Pair 1 & cwbo \& cwbi & 31 &, 941 &, 000 \\
\cline { 2 - 5 }
\end{tabular}

Hipotesis nol pada perhitungan ini adalah tidak ada perbedaan antara rata-rata nilai CWBo dan CWBi. Perbedaan mean antara CWBo dan CWBi adalah .02 dengan nilai signifikansi .760. Dengan demikian Ho diterima. Rata-rata mean CWBo dan CWBi adalah sama. Hal ini berarti karyawan PT X melakukan CWB kepada perusahaan dan rekan kerja dalam tingkat yang sama. 


\begin{tabular}{|c|c|c|c|c|c|c|c|c|}
\hline \multicolumn{9}{|c|}{ Tabel 11 Paired Samples Test } \\
\hline & \multicolumn{5}{|c|}{ Paired Differences } & \multirow[b]{3}{*}{$\mathrm{t}$} & \multirow[b]{3}{*}{$\mathrm{df}$} & \multirow{3}{*}{$\begin{array}{l}\text { Sig. (2- } \\
\text { tailed) }\end{array}$} \\
\hline & \multirow[b]{2}{*}{ Mean } & \multirow{2}{*}{$\begin{array}{c}\text { Std. } \\
\text { Deviation }\end{array}$} & \multirow{2}{*}{$\begin{array}{l}\text { Std. Error } \\
\text { Mean }\end{array}$} & \multicolumn{2}{|c|}{$\begin{array}{c}95 \% \text { Confidence Interval } \\
\text { of the Difference }\end{array}$} & & & \\
\hline & & & & Lower & Upper & & & \\
\hline $\begin{array}{c}\text { Pair } 1 \text { cwbo - } \\
\text { cwbi }\end{array}$ & ,02000 & ,36096 & ,06483 &,- 11240 &, 15240 & ,308 & 30 & ,760 \\
\hline
\end{tabular}

Tingkat CWB di PT X dalam kategori sedang dipengaruhi oleh banyak hal, yaitu konstruksi alat kuesioner, penyajian kuesioner, kesediaan partisipan untuk menjawab dengan jujur. Dalam jurnalnya, Bennett \& Robinson (2000) menyebutkan bahwa salah satu kekurangan dari alat ukur nya adalah tidak mengukur semua aspek atau kategori CWB. Dalam hal ini, ada kemungkinan CWB dimensi Theft dari dari Spector, Fox, Penney, et al (2006) tidak muncul dan misalkan saja munculpun akan menimbulkan keraguan partisipan dalam menjawab karena sifat pertanyaan yang sensitif. Penyajian kuesioner yang ada isian data pribadi harus dijadikan evaluasi peneliti

\section{KESIMPULAN DAN SARAN}

\section{Kesimpulan}

Secara deskriptif, partisipan laki-laki $(93,5 \%)$ lebih banyak daripada partisipan perempuan $(6,5 \%)$ dan karyawan terbanyak adalah lulusan S1 $(48,4 \%)$, kemudian SMA $(25,8 \%)$, S2 $(16,1 \%)$ dan Diploma $(9,7 \%)$. Tingkat CWB di PT X tergolong sedang (skor $\mathrm{z}=.087$ ), tingkat CWBo termasuk kategori sedang (skor $\mathrm{z}=.097$ ), dan tingkat $\mathrm{CWBi}$ tergolong dalam kategori sedang (skor $\mathrm{z}=.077$ ). Tidak ada perbedaan antara rata-rata CWBo dan CWBi di PT X. Perlu diperhatikan masalah konstruksi alat tes, penyajian kuesioner, dan anonimitas partisipan.

\section{Saran}

Peneliti menyarankan agar ada penelitian yang lebih komprehensif terutama dengan melibatkan subjek yang lebih besar sehingga bisa dilakukan analisis yang lebih baik dan mendalam dan dilakukan secara anonim.

\section{Ucapan Terima Kasih}

Peneliti mengucapkan banyak terima kasih kepada Dosen Pembimbing kami yaitu Dr Zamralita, M.M., Psi. yang senantiasa penuh kesabaran membimbing kami dalam perencanaan, pelaksanaan dan penulisan hasil penelitian ini. Peneliti juga mengucapkan terima kasih yang tak terhingga kepada Dr. P. Tommy Y. S. Suyasa, Psi. yang memberikan ijin kepada peneliti untuk menggunakan kuesioner dan membimbing peneliti dalam melakukan analisa data hasil penelitian.

\section{REFERENSI}

Bennett, R. J., \& Robinson, S. L. (2000). Development of a measure of workplace deviance. Journal of Applied Psychology, 85(3), 349-360. (Diadaptasi ke dalam Bahasa Indonesia oleh Suyasa, P. T. Y. S., 2013) 
Koopmans, L., Bernaards, C.M., Hildebrandt, V.H., et al. (2011). Conceptual frameworks of individual work performance a systematic review. Journal of Occupational and Environmental Medicine. 53(8)

Raver, J.L. (2007). Counterproductive work behaviors. Encyclopedia of Industrial and Organizational Psychology, edited by Steven G. Rogelberg, 1, 118-119.

Rodopman, O.B., \& Spector, P.E. (2007). Counterproductive work behaviors, organizational deviance. Encyclopedia of Industrial and Organizational Psychology, edited by Steven G. Rogelberg, 1, 122-126.

Spector, P.E., Fox, S., Penney, et al. (2006). The dimensionality of counterproductivity: Are all counterproductive behaviors created equal?. Journal of Vocational Behavior, 68, 446-460, doi:10.1016/j.jvb.2005.10.005 